\title{
SOCIAL MEDIA AND ACCESS TECHNOLOGIES AS FACTORS OF INFORMATION AND INFLUENCE IN FRESHMEN STUDENTS OF A HIGHER EDUCATION INSTITUTION
}

\author{
Péricles José Pires*, Bento Alves da Costa Filho** and Rômulo Barreto Castelo Branco** \\ *Universidade Federal do Paraná - Departamento de Administração, Brazil \\ **Centro Universitário Alves Faria - Goiânia/GO, Brazil
}

\begin{abstract}
Social media has revolutionized the way people communicate and interact, making it easier and faster for people to get in touch with each other. This study aimed to evaluate the influence of social media on incoming students selected and chosen by the Higher Education Institution (HEI). Based on recent research, this paper proposes the application of a Dutch (Constantinides, 2001) and a Brazilian study (Branco, 2018), about the influence of social media in the decision process of selecting higher education institutions. In order to carry out the research, a survey with 464 respondents was applied in a Brazilian university, with freshmen students in the courses of the Applied Social Sciences area like business administration, accounting and others. The questionnaire was constructed using five point Likert scale. Data treatment was made via cluster, factor analysis and analysis of variance. The questions were structured in 5 (five) main groups: Use of Social Media; Social Media Activities; Channels used to search for information about HEIs; Influence factors in choosing a HEI and Socioeconomic and Demographic Information. The findings of the research indicate the existence of three distinct segments in the population of incoming students regarding social media activities: social engagement; information seeking and content contribution. The results showed that this sample is very adherent to the use of social media and the Internet as an information agent. In addition, it was possible to group individuals into three clusters, based on their social media habits and the main influences on the choice of higher education. Among the social media access platforms, WhatsApp (98.7\%) has a large daily adherence, with concentrated uses between 3 to 6 hours per day (62.1\%) and also amazing uses by $6.7 \%$ of respondents with more than 10 hours a day. Youtube as well has a great use, concentrating between 1 to 3 hours a day. Social media is an important source of "information for students", with about $65 \%$ claiming to use such platforms for this matter. It is worth highlighting the great importance of the "Higher Education Institution websites" as much as "families, friends and acquaintances". Among the items with low membership are blogs, forums, flyers and billboards, visiting programs, as well as traditional radio and television ads. Decisive factors in the process of choosing an HEI were the perception that it forms skilled professionals for the market, the interest in the courses offered and the quality of education. The research also points out the influence of friends and family in the decision making. The offering of cultural activities has a low appeal when making this decision. As presented by the research conducted by Constantinides and Stagno (2011), and Branco (2108), the results show the possibility of replicating the methodology as a basis for understanding social media as a factor of influence, as well as allowing the comparison of results among students from different countries, distinct regions and diverse level of instruction.
\end{abstract}

\section{KEYWORDS}

Social Media and Technology, Higher Education, Freshman Profile

\section{INTRODUCTION}

Since when introduced, social media has transformed the way people relate to each other, and considering the fast increase and high degree of involvement in the dynamic of relationships, they have been object of academic studies as much as commercial interest (Constantinides; Stagno, 2011). This way of relationship has transformed the interaction among society, communication and marketing, providing one interpretation of the information society concept, characterized by the capacity of its members to get and share any information, from anywhere in the most appropriate form (Castells, 2003). 
This paper presents a study based on Constantinides and Stagno (2011) and Branco (2018), which were focused on the higher education context of the social media use in the Netherlands and in Brazil, respectively. The objectives of our study are twofold: (a) describe the characteristics of potential students for a higher education institution, through a segmentation based on the use of social media; (b) explore the social media as a factor of influence in the choice of a course and an education institution.

\section{SOCIAL MEDIA IN HIGHER EDUCATION INSTITUTIONS}

The use of social media is a worldwide phenomenon, with 2.77 billion estimated adopters in the planet according to Statista (2019). In 2018, from a total of 2.62 billion users in many platforms at least $68.3 \%$ had profiles in one of them. They are considered as a turnaround in terms of teaching and learning (Healy, 2015). Its upsurge caused deep impacts in the society, transforming the relationship among people, industries and universities (Qualman, 2009). Social media can be defined as the use of web-based technologies to create interactive platforms where individuals and community generate, share and discuss diverse themes (Kietzmann et al., 2011). Recent research demonstrates that the use of social media provides self-motivation in an informal and autonomous environment (Dabbagh; Kitsantas, 2012). Besides that, they can promote a relevant relationship among actual and potential students of an educational institution (Hayes; Ruschman; Walker, 2009).

\section{METHOD}

The research developed in this study was a survey with 464 freshmen from a higher education public institution in the Brazilian state Parana, enrolled in the courses of Applied Social Sciences (Business, Accounting, Economics and Informatics). The main purpose was to compare the grouping provided by principal components analysis (PCA) with social media habits identified in previous works, namely: content sharing and generation; relationship and entertainment; and content consumption.

\subsection{Data Collection}

The data collection was carried on at the beginning of 2019, through the application of a survey answered in classrooms by freshmen of undergraduate social applied courses. Before the application with 464 respondents, a pre-test was conducted with 35 students in order to validate the social media platforms before the field work. As mentioned before, the questionnaire was constructed based on Constantinides and Stagno (2011) and Branco (2018) and its structure had five main blocks: (1) use of social media; (2) activities in social media; (3) channels for search of information about higher education institutions; (4) factors influencing the choice of a higher education instituition; (5) Demographic and socioeconomic information about respondents.

\section{DATA ANALYSIS AND RESULTS}

\subsection{Sample Profile}

The respondents were $39.2 \%$ women and $60.8 \%$ men; the predominant age range was 18 to 24 years old (70.3\%), reflecting a group of young students beginning their academic career. Family income was distributed as follows: $35.0 \%$ up to US\$ $1500 ; 28.2 \%$ from US\$ 1501 to $3000 ; 17.7 \%$ from US\$ 3001 to $5000 ; 17.9 \%$ from US\$ 5001 upwards. Considering the type of educational institution, $57.6 \%$ of the respondents were from public high schools and $42.4 \%$ from private ones. The majority are social media users, $96.9 \%$. 


\subsection{Factors related to the use of Social Media Platforms}

Among the social media platforms, the one with greatest daily adoption is WhatsApp (98.7\%), with 1 to 6 hours a day $(62.1 \%)$; a small percentage $(6.7 \%)$ uses more than 10 hours a day (Table 1). Youtube also has large utilization, between 1 to 6 hours a day, accounting for $52.2 \%$ of the sample. Those platforms directed to professional uses, like Linkedin and Skype, have lower daily usage by the respondents.

Table 1. Daily use of social media platforms

\begin{tabular}{lccccccc}
\hline & $\begin{array}{c}\text { Do not } \\
\text { use }\end{array}$ & $\begin{array}{c}\text { Up to 1h a } \\
\text { day }\end{array}$ & $\begin{array}{c}\text { From 1 } \\
\text { to 3 h a } \\
\text { day }\end{array}$ & $\begin{array}{c}\text { From 3 to } \\
\mathbf{6} \text { h a day }\end{array}$ & $\begin{array}{c}\text { From 7 to } \\
\mathbf{1 0} \text { h a day }\end{array}$ & $\begin{array}{c}\text { More than 10 } \\
\text { h a day }\end{array}$ & $\begin{array}{c}\text { Total } \\
\text { Utilization }\end{array}$ \\
\hline Whatsapp & $1,3 \%$ & $14,3 \%$ & $31,4 \%$ & $30,7 \%$ & $15,6 \%$ & $6,7 \%$ & $100 \%$ \\
\hline Youtube & $4,4 \%$ & $38,6 \%$ & $37,1 \%$ & $15,1 \%$ & $4,6 \%$ & - & $100 \%$ \\
\hline Facebook & $16,4 \%$ & $47,2 \%$ & $26 \%$ & $7,1 \%$ & $2,6 \%$ & - & $100 \%$ \\
\hline Instagram & $18,7 \%$ & $31,3 \%$ & $36,1 \%$ & $10,6 \%$ & $2,6 \%$ & $0,9 \%$ & $100 \%$ \\
\hline Twitter & $58,7 \%$ & $16,7 \%$ & $13,8 \%$ & $8,2 \%$ & $1,6 \%$ & $1,1 \%$ & $100 \%$ \\
\hline Google+ & $60,2 \%$ & $22,9 \%$ & $10,7 \%$ & $3,8 \%$ & $1,1 \%$ & $0,7 \%$ & $100 \%$ \\
\hline Linkedin & $79,2 \%$ & $17,9 \%$ & $1,8 \%$ & $0,9 \%$ & $0,2 \%$ & - & $100 \%$ \\
\hline Skype & $90,8 \%$ & $7,2 \%$ & $0,4 \%$ & $0,9 \%$ & $0,7 \%$ & - & $100 \%$ \\
\hline Telegram & $95,8 \%$ & $2,7 \%$ & $1,1 \%$ & $0,2 \%$ & $0,2 \%$ & - & $100 \%$
\end{tabular}

Source: Authors (2019)

Table 2. Freshmen students use of social media

\begin{tabular}{|c|c|c|c|c|c|c|c|}
\hline Frequency & 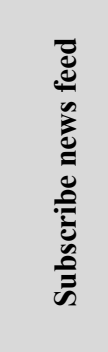 & 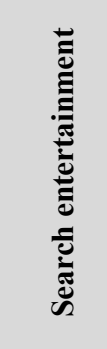 & 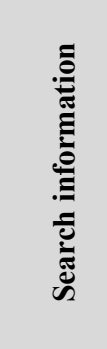 & 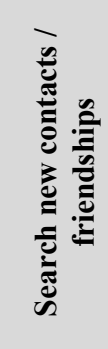 & 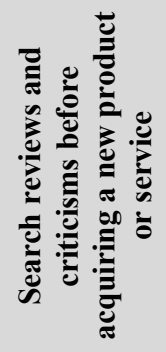 & 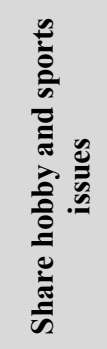 & 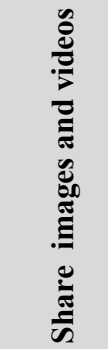 \\
\hline Never & $29,6 \%$ & $1,1 \%$ & $2 \%$ & $11,9 \%$ & $2,6 \%$ & $38,6 \%$ & $6,5 \%$ \\
\hline Few times & $27,4 \%$ & $5,4 \%$ & $4,7 \%$ & $44,2 \%$ & $11,4 \%$ & $32,8 \%$ & $35,8 \%$ \\
\hline Sometimes & $23,8 \%$ & $25,9 \%$ & $26 \%$ & $29,3 \%$ & $28 \%$ & $18,8 \%$ & $26,9 \%$ \\
\hline Many times & $12,5 \%$ & $48,9 \%$ & $45,3 \%$ & $9,3 \%$ & $30,87 \%$ & $6,9 \%$ & $18,5 \%$ \\
\hline Frequently & $4,8 \%$ & $17,7 \%$ & $23,8 \%$ & $3,9 \%$ & $25,9 \%$ & $3 \%$ & $12,3 \%$ \\
\hline Frequency & 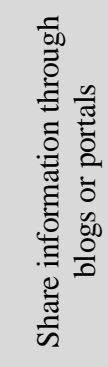 & 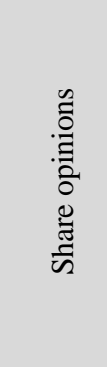 & 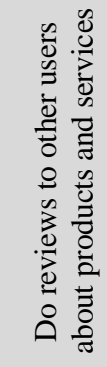 & 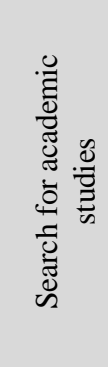 & 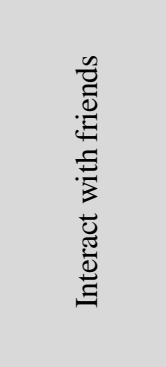 & 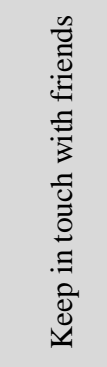 & 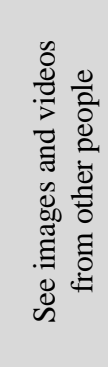 \\
\hline Never & $55,8 \%$ & $57,8 \%$ & $37,9 \%$ & $2,4 \%$ & $0,7 \%$ & $3,9 \%$ & $1,5 \%$ \\
\hline Few times & $24,3 \%$ & $28,8 \%$ & $36,5 \%$ & $10,2 \%$ & $7,2 \%$ & $13,9 \%$ & $18,6 \%$ \\
\hline Sometimes & $11,9 \%$ & $9,1 \%$ & $17 \%$ & $27,5 \%$ & $17 \%$ & $26,7 \%$ & $42,4 \%$ \\
\hline Many times & $5,4 \%$ & $3 \%$ & $6,9 \%$ & $36,7 \%$ & $36,4 \%$ & $29,9 \%$ & $74,5 \%$ \\
\hline Frequently & $1,7 \%$ & $1,3 \%$ & $1,7 \%$ & $23,2 \%$ & $38,8 \%$ & $25,6 \%$ & - \\
\hline
\end{tabular}


On the one hand, taking into consideration the habits of use in social media by the respondents, i.e., what the students do in these web spaces (Table 2), the most frequent mentioned activities are search for entertainment, for information, for academic studies, interaction with other users, contact with friends, and also with high emphasis the sharing of videos and images. On the other hand, activities like feeds subscription, share of hobbies and sports and information sharing through blogs and portals still have lower adoption by the students (respondents).

In general the behaviors presented suggest an ever more relevant role of social media as an agent of information and source of pertinent issues by the students in their daily academic activities. This situation reinforces the importance of mechanisms of quality verification to check the credibility of these platforms against the chances of fake news and malpractices.

\subsection{Principal Components and Cluster Analysis}

Principal components analysis (PCA) can be used to explore standards or relationships among variables indicating if they can or not be grouped in factors (Hair et al., 2005). This statistical analysis is used here in conjunction with cluster analysis in order make a cross comparison between factors and profiles of the respondents. Table 3 depicts the use of social media according the access factor.

Table 3. Principal Components Analysis - Varimax Rotation - Use of Social Media

\begin{tabular}{|c|c|c|c|c|c|c|c|c|c|}
\hline & \multicolumn{3}{|c|}{$\begin{array}{c}\text { Factor } \\
1\end{array}$} & \multicolumn{3}{|c|}{$\begin{array}{c}\text { Factor } \\
2\end{array}$} & \multicolumn{3}{|c|}{$\begin{array}{c}\text { Factor } \\
3 \\
\end{array}$} \\
\hline & 2011 & 2018 & 2019 & 2011 & 2018 & 2019 & 2011 & 2018 & 2019 \\
\hline Share hobby and sports issues & 0,533 & 0,730 & 0,694 & & & & & & \\
\hline Share opinions & 0,613 & 0,692 & 0,723 & & & & & & \\
\hline $\begin{array}{l}\text { Share information through } \\
\text { blogs or portals }\end{array}$ & 0,732 & 0,690 & 0,694 & & & & & & \\
\hline $\begin{array}{l}\text { Do reviews to other users about } \\
\text { products and services }\end{array}$ & 0,652 & 0,592 & 0,622 & & & & & & \\
\hline Subscribe news feed & 0,577 & 0,532 & $0,088 *$ & & & & & & \\
\hline Interact with friends & & & & 0,871 & 0,830 & 0,827 & & & \\
\hline Keep in touch with friends & & & & 0,805 & 0,809 & 0,786 & & & \\
\hline Share images and videos & & & & 0,726 & 0,592 & 0,578 & & & \\
\hline $\begin{array}{l}\text { See images and videos from } \\
\text { other people }\end{array}$ & & & & 0,817 & 0,591 & 0,793 & & & \\
\hline Search entertainment & & & & 0,613 & 0,474 & 0,457 & & & \\
\hline $\begin{array}{l}\text { Search new contacts / } \\
\text { friendships }\end{array}$ & & & & 0,501 & 0,424 & 0,446 & & & \\
\hline Search information & & & & & & & 0,849 & 0,767 & 0,584 \\
\hline Search for academic studies & & & & & & & 0,882 & 0,751 & 0,754 \\
\hline $\begin{array}{l}\text { Search reviews and criticisms } \\
\text { before acquiring a new product } \\
\text { or service }\end{array}$ & & & & & & & 0,500 & 0,663 & 0,751 \\
\hline
\end{tabular}

Source: Adapted from Constantinides and Stagno (2011); Branco (2018); Authors (2019)

*not fitted in the Factor

As can be seen in Table 3, the principal components analysis (PCA) results presented a grouping of three factors. It is possible to describe this grouping based on the characteristics of its variables: Factor 1 - variables related to generation and sharing of content; Factor 2 - variables related to social activities and entertainment; and Factor 3 - variables related to content consumption. The results obtained in the analysis were in line with the previous findings of Constantinides and Stagno (2011), and Branco (2018). This shows that the factors identified in the three research are consistent from an academic investigation point of view.

The cluster analysis was made based on the variables "use of social media" presented in Table 3 . Using the K-means method, three groups were indicated and the quantities in each one were 169 members for Cluster 1; 114 for Cluster 2 and 170 for Cluster 3. As shown in Table 4, Cluster 2 was the one with higher means $(2,85)$, i.e., intensively reflecting the Factors "Generation and Sharing Content", "Social Activities and Entertainment", and "Content Consumption”, followed by Cluster 1 (mean = 2,69) and Cluster $3(2,51)$. 
Table 4. Factors X Clusters

\begin{tabular}{l|c|c|c}
\hline FACTORS versus CLUSTERS & $\begin{array}{c}\text { Cluster 1 } \\
\mathbf{N = 1 6 9}\end{array}$ & $\begin{array}{c}\text { Cluster 2 } \\
\mathbf{N = 1 1 4}\end{array}$ & $\begin{array}{c}\text { Cluster 3 } \\
\mathbf{N = 1 7 0}\end{array}$ \\
\hline Factor 1 - Generation and Sharing of Content & 3,03 & 3,21 & 2,82 \\
\hline Factor 2 - Social Activities and Entertainment & 3,03 & 3,21 & 2,82 \\
\hline Factor 3 - Content Consumption & 2,02 & 2,14 & 1,88 \\
\hline General mean & $\mathbf{2 , 6 9}$ & $\mathbf{2 , 8 5}$ & $\mathbf{2 , 5 1}$ \\
\hline
\end{tabular}

\section{CONCLUDING REMARKS}

The results suggest a considerable influence social media exert on respondents as a source of information about a higher education institution. The study also has shown the possibility of grouping the students according to the way they use the social media.

The findings of Constantinides and Stagno (2011), and Branco (2018) were confirmed in this study. This can be interpreted with optimism regarding the proposed model developed to assess social media through a group of factors focused in content generation, sharing, and consumption as much as in social activities in which respondents were involved.

It is worth to mention that the transformations observed in the higher education in Brazil demand increasingly from the educational institutions the consolidation of an institutional identity in which the high quality contact with their "clients", i.e., the students, should be the leitmotif. The results pointed to the necessity the HEI have to look for a communication capacity able to create a bridge between basic and superior education. This communication competence can be highly reinforced with the aid social media has been providing through World Wide Webb.

For future research we suggest the application of this methodology in diverse areas of the country (Brazil) as much as in other countries in order to permit the observation of regional differences, and eventually anticipating trends in behavior and following up the transformations provided by these new communication media. Aiming at capturing the dynamics of the proposed model, we also suggest the application in a diversity of courses what could promote interesting and useful insights for stakeholders in higher education.

\section{REFERENCES}

Branco, Rômulo Barreto Castelo. Mídias sociais: um instrumento de marketing para a seleção e escolha de instituições de ensino superior privadas. (Mestrado Profissional em Administração). UNIALFA - Centro Universitário Alves Faria, Goiânia, 2018.

Brech, Felicitas M.; Messer, Uwe; Schee, Brian A. Vander; Rauschnabel, Philipp A.; Ivens, Bjoern S. Engaging fans and the community in social media: interaction with institutions of higher education on Facebook. Journal of Marketing for Higher Education, v.27 (1), p. 112-130, 2017.

Casella, G; Berger, R. L. Inferência Estatística. São Paulo: Cengage Learning, 2010.

Castells, M. Internet e Sociedade em Rede. In: MORAES, D. de (Org.). Por uma outra Globalização: mídia, mundialização cultural e poder. Rio de Janeiro: Record, 2003.

Comitê Gestor da Internet no Brasil - CGI.br (2018). Pesquisa sobre o uso das tecnologias de informação e comunicação nos domicílios brasileiros: TIC Domicílios 2017. São Paulo: CGI.br.

Constantinides, E; Stagno, M. C. Z. Potential of the social media as instruments of higher education marketing: a segmentation study. Journal of Marketing for Higher Education, v. 21, n. 1, p. 7-24, 2011.

Dabbagh, N.; Kitsantas, A. Personal Learning Environments, Social Media, and Self-regulated Learning: A Natural Formula for Connecting Formal and Informal Learning. The Internet and Higher Education, v.15(1), p. 3-8, 2012.

Hair, J. F.; Anderson, R. E.; Tatham, R. L.; Black, W. C. Análise multivariada de dados. 5. ed. Porto Alegre: Bookman, 2005.

Hall, Hanna; Witek, Lucyna. Conditions, Contemporary Importance and Prospects of Higher Education Marketing on the Example of Polish Universities. Procedia Economics and Finance, v. 39, p. 206-211, 2016. 
Harris, A. L.; Rea, A. Web 2.0 and virtual world technologies: A growing impact on IS education. Journal of Information Systems Education, 20(2), 137-144, 2009.

Hayes, T. J.; Ruschman, D.; Walker, M. M. Social Networking as an Admission Tool: A Case Study in Success. Journal of Marketing for Higher Education, v. 19(2), p. 109-124, 2009.

Healy, Frank. Technology and the changing education landscape. 2015. Disponível em: <http://www.leadscon.com/technology-changing-education-landscape/>. Acesso em: 26 de maio de 2017.

Kietzmann, Jan H.; Hermkens, Kristopher; Mccarthy, Ian P.; Silvestre, Bruno S. Social media? Get serious! Understanding the functional building blocks of social media. Business Horizons, v. 54(3), p. 241-251, 2011.

Qualman, Erik. Socialnomics: how social media transforms the way we live and do business. New Jersey: Wiley, 2009.

Raacke, John; Raacke, Jennifer Bonds. Myspace and Facebook: applying the uses and gratifications theory to exploring friend-networking sites. CyberPsychology \& Behavior, Pembroke, v. 11, n. 2, p. 169-174, 2008.

Ramasubramanian, S.; Gyure, J. F.; Mursi, N. M. Impact of Internet images: Impression-formation effects of university Web site images. Journal of Marketing for Higher Education, v. 12, p. 59-68, 2002.

Rauschnabel, Philipp A.; Krey, Nina; Babin, Barry J.; Ivens, Bjoern S. Brand management in higher education: The University Brand Personality Scale. Journal of Business Research, v.69, p.3077-3086, 2016.

Reddy, Vijay Paul. The influence of social media on international students' choice of university and course. Dissertação (Master of Information Technology). School of Information Systems. Queensland University of Technology, Austrália, 2014.

Reis, Fábio; Capelato, Rodrigo. A relevância do ensino superior privado no Brasil. Revista Educación Superior em América Latina (ESAL), v. 1, p. 26-29, 2017.

SEMESP. Mapa do Ensino Superior no Brasil. 2016. Disponível em: <http://convergenciacom.net/pdf/mapa_ensino_superior_2016.pdf>. Acesso em: 13 de maio de 2019.

Smith, A. U.S. Smartphone Use in 2015. PewResearchCenter: Internet, Science \& Tech. 2015. Disponível em: <http://www.pewinternet.org/2015/04/01/us-smartphone-use-in-2015/>. Acesso em: 21 de maio de 2017.

STATISTA. Number of social network users worldwide from 2010 to 2020 . Disponível em: <https://www.statista.com/statistics/278414/number-of-worldwide-social-network-users/>. Acesso em: 19 de março de 2019.

Vinerean, Simona; Cetina, Iuliana; Dumitrescu, Luigi; Tichindelean, Mihai. The effects of Social Media Marketing on Online Consume Behavior. International Journal of Business and Management; v. 8, n. 14, p. 66-79, 2013. 